\title{
Derivative prefixes to form nouns in Indonesian
}

M. Wildan Fathurrohman a, 1*, Hanifah Yulia P. S. b, ${ }^{2}$, Isabella Enola D. A. K. c, ${ }^{3}$, Tias Nur K. c, 4

a Indonesian Language and Literature, Faculty of Cultural Science, Universitas Sebelas Maret

1 mwildanI408@gmail.com *; hanifahyuliaputri@gmail.com; enoladheaa@student.uns.ac.id; tiasnk27@gmail.com

* corresponding author

\begin{tabular}{ll}
\hline \multicolumn{2}{l}{ Article's information } \\
\hline History: & \\
Submitted & $: 8$ Desember 2020 \\
Revised & $:$ I7 April 202I \\
Published & $: 30$ April 202I \\
\hline
\end{tabular}

Kata kunci:

Prefiks Derivasi, Nomina, Bahasa Indonesia \begin{abstract}
ABSTRAK
Penelitian ini membahas perihal ragam prefiks derivasi pembentuk nomina yang terdapat dalam tulisan fiksi, nonfiksi, dan teks berita. Masalah yang dikaji yaitu proses morfologis berupa afiksasi (prefiks) pembentuk nomina bahasa Indonesia yang ditinjau dari perspektif derivasi. Penelitian ini berjenis deskriptif dengan pendekatan kualitatif. Adapun data pada penelitian ini berupa prefiks derivasi yang membentuk nomina. Teknik pengumpulan datanya menggunakan metode simak dan teknik catat, metode simak digunakan untuk meninjau buku maupun teks berita dengan teliti, sedangkan teknik catat digunakan untuk menuliskan prefiks derivasi pembentuk nomina yang dijumpai dalam buku maupun teks berita. Selanjutnya teknik analisis datanya dilakukan dengan metode agih dan teknik bagi unsur langsung. Setelah dianalisis berdasarkan proses pembubuhan afiks maka berikutnya akan dianalisis proses perubahan kelas katanya. Simpulan penelitian ini terdapat empat prefiks derivasi pembentuk nomina dalam bahasa Indonesia yakni prefiks $\{\mathrm{ke}-\},\{\mathrm{pe}-\}$, $\{$ per- $\}$, dan $\{$ se- $\}$. Prefiks derivasi tersebut berfungsi membentuk nomina dari kelas kata dasar adverbia, adjektiva, dan verba. Pola prefiks derivasi pembentuk nomina dapat dirumuskan sebagai berikut $\{\mathrm{ke}-\}+\mathrm{Adv}=\mathrm{N}$, $\{$ ke- $\}+\mathrm{A}=\mathrm{N},\{\mathrm{ke}-\}+\mathrm{V}=\mathrm{N},\{\mathrm{pe}-\}+\mathrm{A}=\mathrm{N},\{\mathrm{pe}-\}+\mathrm{V}=\mathrm{N}$, $\{$ per- $\}+\mathrm{V}=\mathrm{N},\left\{\mathrm{se}_{-}\right\}+\mathrm{A}=\mathrm{N}$, dan $\left\{\mathrm{se}_{-}\right\}+\mathrm{V}=\mathrm{N}$.

\section{ABSTRACT}

\section{Keywords:}

Derivation Prefix, Noun. Indonesian Language
This research discusses the variety of derivative prefixes that form nouns found in fiction, non-fiction, and news texts. The problem studied is the morphological process in the form of affixations (prefixes) forming Indonesian nouns from a derivation perspective. This research is a descriptive type with a qualitative approach. The data in this study are in the form of derivation prefixes that form nouns. The data collection technique uses the observing method and note-taking technique, the observing method is used to review books and news texts carefully, while the note-taking technique is used to write in derivative prefixes to form nouns found in books and news texts. Furthermore, the data analysis technique was carried out by using the split method and technique for direct elements. After being analyzed based on the affix affixing process, the next process will be analyzed the class change process. The conclusion of this research is that there are four derivative prefixes to form nouns in Indonesian, namely the prefix $\{$ ke- $\},\{$ pe- $\},\{$ per- $\}$, and $\{$ se- $\}$. These derivative prefixes function to form nouns from the base class of adverbs, adjectives, and verbs. The derivative pattern of noun-forming prefixes can be formulated as follows: $\{$ ke- $\}+$ Adv $=\mathrm{N},\{$ ke $\}+\mathrm{A}=\mathrm{N},\{\mathrm{ke}-\}+\mathrm{V}$ $=\mathrm{N},\{$ pe -$\}+\mathrm{A}=\mathrm{N},\{$ pe $\}+\mathrm{V}=\mathrm{N},\{$ per- $\}+\mathrm{V}=\mathrm{N},\{$ se -$\}+\mathrm{A}=$ $\mathrm{N}$, and $\{\mathrm{se}-\}+\mathrm{V}=\mathrm{N}$.

Copyright (C) 2018 Universitas Ahmad Dahlan. All Right Reserved 


\section{Introduction}

Language can never be separated from all human activities, this is due to the very close bond and relation between humans and language i.e. humans as the creator of language. On the other hand, human life that continues to change with the times causes language to shift, not remain, dynamic. The shift that occurs most often or is seen is at the lexicon level (vocabulary).

This can be seen especially in Indonesian because this language is an agglutinative language. As an agglutinative language, Indonesian certainly has a variety of vocabulary resulting from the process of word formation, one of which is the addition to the roots. These processes are studied in one of the branches of linguistics i.e. morphology.

Morphology is a branch of linguistic studies. The level of morphology in linguistics occupies a grammatical functional structure that is closely related to other branch of linguistics i.e. syntax. Research on morphology is limited to the construction of form and meaning. Morphology has been clearly described by linguists, both foreign and Indonesian linguists.

Ramlan (2009: 2I) proposed that morphology is a branch of linguistics that studies word formation and the effect of its changes on meanings and groups of words. Therefore, it can be said that morphology examines everything related to the form of words and the function of these changes, both in grammatical and semantic functions. The morphological study will discuss the smallest meaningful grammatical unit or what is called morpheme. There are two types of morphemes, namely free morphemes and bound morphemes. Free morpheme is a morpheme that can stand alone without any other morphemes in an utterance. Meanwhile, bound morphemes are morphemes that require the presence of other morphemes in an utterance.

On the other hand, Nida said that morphology is the study of morphemes and their arragements in forming words (1952: I). Another linguist, Booij,stated that the term 'morphology' refers to the study of internal structure of words, and of the systematic form-meaning correspondesnces between words (2007: 7). In line with Booij, Verhaar argues that morphology is a study of linguistics that deals with internal structures, each of which becomes a word-forming element, hereinafter known as morpheme (2016: II).

Based on these previous descriptions, the researcher could summarize that morphology is a study of the grammatical structure, especially the internal structure of words, which includes the formation of words from the smallest elements in the form of morphemes. The next attention is focused on how the word is formed and the process of its formation from input to output in the scope of grammatical meaning.

One of the studies in morphology is about word formation through the affixation process. The affixation process is carried out by attaching a bound morpheme to another lingual unit. Word formation uses an affixation process associated with changes in inflection and derivation. As has been explained by Verhaar (2016: I43) that in inflection there is a morphemic change that maintains lexical identities, whereas in derivation there are morphemic changes which then form new words with different lexical identities. The difference is that in inflectional morphology there is no change in the identity of both the word class and semantic features, while in derivational morphology there is a change in word class and semantic features. There is a note,however, that if the word class does not change but its semantic features change, it is still classified as a derivation change.

On the other hand, along with the times, the study of word formation or morphology has also developed. In today's era, you can find many words with affixes both in print and digital media. Therefore, this study examined the noun-forming derivative prefixes in Indonesian.

The following are previous studies that are indirectly relevant to this research. The first research was conducted by Kridalaksana (2007) which revealed several types of noun-forming affixes such as prefixes (ke-, pe, per-, se-); infix (-el-, -er-); sufixes (-an, -at, -si, -ika, -in, -ir, -ur, -ris, -us, -isme, -is, -isasi, -isida, -ita, -or, -tas); confix (ke-an, pe-an, per-an); and affix combinations (pemer-, keber-an, kese-an, keter-an, pember-an, pemer-an, penye-an, perse-an, perseke-an).

Then the research conducted by Ermanto and Emidar (20II) states that when viewed from a morphological perspective of derivation and inflection, the affixing of derivative affixes to nouns and verbs can derive and form nouns of action, instrument, instrument of action, process, collective, and abstract.

Research related to prefixes and derivations has been conducted previously by Sunaryo (20I4). This research was conducted to examine the informal conversations of elementary school students. The data taken was in the form of prefixed words in Indonesian. In this study, Sunaryo showed that in the informal speech or conversation of elementary school students, there were several prefixed words in Indonesian such as me, ber-, get, tar-, se-, and pe-. In addition, there are word classes that can be combined with the aforementioned prefixes which include nouns, verbs, adjectives, and numerals. 
Furthermore, research conducted by Setiawan (2017) discusses the affixation of nouns with the prefixes to-, pe-, and ter-; the confixes ke-an, pe-an, dan per-an; and the the suffixes -an and -nya in a collection of short stories titled Lupa Endonesa by Sujiwo Tejo. The results of this study indicated a description of the formation of nouns in affixation. The result was that there were a noun-forming affixation with prefixes to-, pe-, and ter-; nounforming affixation with confixes ke-an, pe-an, and per-an; as well as noun-forming affixation with suffix -an and nya.

Next, research by Nugraha (2017) described the characteristics of denominative verb construction formed from the distribution of derivational and noun affixes. This derivative affixes has the form of prefixes, confixes, simulfixes, and a combination of affixes. The results of this study indicated that denominative verbs in Indonesian tend to change the predicate function. As a derivation construct, denominative verbs are formed because of the distribution between derivative affixes which at least can consist of prefixes, confixes, simulfixes, and a combination of affixes. On the other hand, the types or forms of nouns can consist of basic, authentic, derivative, compound, animate, inanimate nouns, and noun phrases.

The research by Utama (2019) found that affixes form deverbal nouns, namely the prefix peng- and per-; suffix $\neg-$ an and -el; as well as confixes peng-an, per-an, dan ke-an. The affixed words that form the deverbal nouns are compiled through a derivation process which is carried out by attaching the affix to the lexemes. The attachment of these affixes forms several patterns such as per $+\mathrm{D}$, peng $+\mathrm{D}, \mathrm{D}+\mathrm{an}, \mathrm{D}+\mathrm{el}$, peng $+\mathrm{D}+$ an, per $+\mathrm{D}+$ an, and ke $+\mathrm{D}+$ an. In addition to creating patterns of forms, this process also creates patterns of meaning. Meanwhile, the affixes that form deverbal nouns have different productivity.

Finally, the results of research conducted by Zuhro (2019) showed that in the formation of a word, apart from following the perspective of derivation and inflection, it also involved several aspects of morphology. These aspects included affixation, reduplication, and morphophonemic so that they were able to produce word forms that could be used in rules of Indonesian words. The means used to adjust the word forms were usually in the form of affixes or internal modifications. Meanwhile, in determining the process of derivation and inflection, it could be seen whether there were differences in the meanings of affixed verbs and root words which were indicated by differences in identity.

All of the researches that have been previously conducted are related to morphological processes, namely a process of forming words from other lingual units that become their basic form. One of the processes is known as derivation. According to Chaer (2015), derivation is a process of changing form identity from basic form lexical identity. In Indonesian, there is a morphological process, one of which is the affixation of an affix or what is called affixation. Based on the opinion of Ramlan (2009: 2I), affixation is a process of giving affixes to a unit, both units are single and complex. Therefore, if an affix can change its basic form, then the affix is derivative. This is in line with what was conveyed by Purnanto (2006) that there are three ways to find out that an affix is derivative or inflected, one of which is by looking at its basic form, if it changes it is included in a derivative or lexical affix.

An example of this explanation is as follows: the word makan belongs to the verb word class, but after getting the prefix $\{\mathrm{pe}-\}$, the word makan changes to pemakan, where the word class changes to a noun. So, it is clear that the change in word class is due to the prefix $\{\mathrm{pe}-\}$. Therefore, it can be concluded that the prefix $\{$ pe\} undergoes a derivation process which functions to rearrange the class of verbs into nouns or function as a tool used to form nouns.

\section{Method}

This research was classified as a qualitative descriptive study to systematically describe the meaning of language which was then grouped according to certain patterns for analysis. According to Subroto (2010: 7-8) qualitative methods are research methods that are not designed to use statistical procedures. This research was descriptive in nature which was intended to parse the linguistics phenomena that occur in order to make a description as it is. Meanwhile, the data in this study were in the form of sentences in which words with derivative affixes were found, in this case noun-forming prefixes in Indonesian. The data in this study were taken from the Solopos newspaper, Eka Kurniawan's book, a collection of short stories Corat-coret di Toilet, and the book of Panduan Pembaca Teori Sastra Masa Kini by Raman Selden. The reason is because in addition to a lot of data being found, there were also various written languages in Indonesian, namely the informal and formal varieties. Sources of data in the study were presented in table I. 
Table 1. Research Data Sources

\begin{tabular}{llc}
\hline No. & \multicolumn{1}{c}{ Data Sorces } & Amount of Data \\
\hline 1. & $\begin{array}{l}\text { Buku Kumpulan Cerpen } \\
\text { Corat-Coret di Toilet }\end{array}$ & 44 \\
2. & $\begin{array}{l}\text { Buku Panduan Pembaca Teori } \\
\text { Sastra Masa Kini }\end{array}$ & 31 \\
3. & Koran Solopos XXIV No. I5 & 35 \\
\hline & Total Data & $\mathbf{1 1 0}$ \\
\hline
\end{tabular}

Based on table I, the amount of data obtained from fiction books (a collection of short stories from CoratCoret di Toilet) was the highest with 44 data compared to two other data sources, such as newspapers (Solopos) and the non-fiction book (Panduan Pembaca Teori Sastra Masa Kini) which were 35 data and 3I data respectively.

The principle of providing data used in this study was the simak method. This method was chosen to listen to words in books and newspapers which will later be used as data. The technique chosen was the note-taking technique. According to Mahsun (2012: 93) that the note-taking technique was the advanced technique that was selected and used when applying the simak method.

Meanwhile, the data analysis used was the split method, with direct element sharing techniques. In this method, the determining tools became part of the related language. On the other hand, data was always in the form of elements from the language of the object of research, such as words, clauses, and syntactic functions. Furthermore, the technique of dividing for direct elements (Bagi Unsur Langsung/BUL) means dividing lingual data units into several elements. Then the related element was seen as a part that immediately becomes the lingual unit in questions (Sudaryanto, 2015: 3I).

\section{Results and Discussion}

Of the IIO data collected from fiction, non-fiction, and newspapers; four derivative prefixes that form nouns were found, namely prefix $\{$ ke- $\},\{$ pe- $\},\{$ per- $\}$, and $\{$ se -$\}$. The details of the number of each prefix are as follows, $\{$ ke- $\}$ prefixes of I2, \{pe- $\}$ prefixes of 62 , \{per- $\}$ prefixes of I5, and $\{$ se- $\}$ of $2 \mathrm{I}$ prefixes. Furthermore, the four prefixes would be described based on the formation process (affixation) and word class changes (derivation).

As previously explained, there are several types of derivative prefixes to form nouns in Indonesian. This linguistic phenomenon can be found in both fiction, non-fiction, and newspapers. This is as seen in data (I).

(I) Kehendak mereka untuk pemahaman total memprakarsai penafsiran "lingkaran hermeneutik".

(Panduan Pembaca Teori Sastra Masa Kini)

In data (I) there is a sentence containing the polymorphemic word, namely kehendak. The word is the result of the affixation process with the prefix as its constituent element. The affixation process can be illustrated as follows:

$$
\{\text { ke- }\}+\text { hendak }(\mathrm{adv})=\operatorname{kehendak}(\mathrm{n})
$$

This affixation affects the change in word class and changes in the original meaning which is known as the derivation process. The word hendak comes from an adverb word class and then after getting the prefix $\{\mathrm{ke}-\}$ it changes to a word class of noun. Meanwhile, in terms of meaning, originally the word hendak meant 'mau', but because of the prefix $\{\mathrm{ke}-\}$ being affixed, the meaning changed to 'kemauan'.

Apart from the prefix $\{\mathrm{ke}-\}$, the prefix $\{\mathrm{pe}-\}$ also changes the word class to a noun. This can be seen in data (2), (3), and (4) below.

(2) Orang segera akan tahu bahwa ia bukan pemuda yang mudah patah semangat.

(Corat-Coret di Toilet) 
In data (2) there is a sentence containing the polymorphemic word pemuda. The word is the result of the affixation process with the prefix as its constituent element. This process can be illustrated as follows:

$$
\{\text { pe }\}+\operatorname{muda}(\mathrm{a})=\operatorname{pemuda}(\mathrm{n})
$$

This affixation affects the change in word class and changes in the original meaning which is known as the derivation process. The word muda comes from the adjective word class and then after getting the prefix $\{\mathrm{pe}-\}$ it changes to a noun. Meanwhile, in terms of meaning, originally the word muda means "not yet half of age", but because of the prefix $\{\mathrm{pe}-\}$ being put on it, the meaning changes to "someone who is still young".

(3) Mereka mencemooh sikap mistik penyair-penyair seperti Briusov dan menyebut mereka "pengawal misteri”".

(Panduan Pembaca Teori Sastra Masa Kini)

In data (3) there is a sentence containing the polymorphemic word pengawal. The word is the result of the affixation process with the prefix as its constituent element. This process can be illustrated as follows:

$$
\{\text { pe- }\}+\operatorname{kawal}(\mathrm{v})=\operatorname{pengawal}(\mathrm{n})
$$

This affixation affects the change in word class and changes in the original meaning which is known as the derivation process. The word kawal comes from a verb word class and then after getting the prefix $\{\mathrm{pe}-\}$ it changes to a word class of noun. Meanwhile, in terms of meaning, originally the word kawal means 'guard (v)', but because of the prefix $\{\mathrm{pe}-\}$ being put on, the meaning changes to 'guard (n)' or 'guardian'.

(4) Keinginan penikmat bola Soloraya untuk menyaksikan laga uji coba antara Persis Solo melawan Persika Karanganyar kian mendekati kenyataan.

(Solopos)

In data (4) there is a sentence containing the polymorphemic word, namely penikmat. The word is the result of the affixation process with the prefix as its constituent element. This process can be illustrated as follows:

$$
\{\text { pe- }\}+\operatorname{nikmat}(\mathrm{a})=\text { penikmat }(\mathrm{n})
$$

This affixation affects the change in word class and changes in the original meaning which is known as the derivation process. The word nikmat is an adjective and then after getting the prefix $\{\mathrm{pe}-\}$ it changes to a noun. Meanwhile, in terms of meaning, originally the word nikmat meant 'delicious' or 'pleasant taste or smell', but because of the prefix $\{\mathrm{pe}-\}$ being put on, the meaning changed to "one who enjoys".

The next type of prefix that goes through the derivation process was the prefix $\{$ per- $\}$. It can be seen in the following data (5), (6), and (7).

(5) Tuan Puteri berkata kepadanya, di mana-mana rakyat begitu miskin sementara para pejabat hidup mewah.

(Corat-Coret di Toilet)

In data (5), there is a sentence that contains the word polymorphemic, namely pejabat. The word is the result of the affixation process with the prefix as its constituent element. This process can be illustrated as follows:

$$
\{\text { per- }\}+\text { jabat }(\mathrm{v})=\text { pejabat }(\mathrm{n})
$$

This affixation affects the change in word class and changes in the original meaning which is known as the derivation process. The word jabat comes from a verb word class and then after getting the prefix $\{$ per- $\}$ it changes to a noun word class. Meanwhile, in terms of meaning, originally the word jabat meant "hold", but due to the prefix \{per-\} being affixed, the meaning changed to "government employee holding an important position".

(6) Seorang tokoh laki-laki mungkin diperankan oleh seorang pemain wanita dengan maksud untuk merusak kealamiahannya.

(Panduan Pembaca Teori Sastra Masa Kini)

In data (6) there is a sentence containing a polymorphemic word pemain. The word is the result of the affixation process with the prefix as its constituent element. This process can be illustrated as follows: 


$$
\{\operatorname{per}-\}+\operatorname{main}(\mathrm{v})=\operatorname{pemain}(\mathrm{n})
$$

This affixation affects the change in word class and changes in the original meaning which is known as the derivation process. The word main comes from a verb and then after getting the prefix \{per- $\}$ it changes to a noun. Meanwhile, in terms of meaning, originally the word main means "to do an activity or activity to please the heart", but because of the prefix \{per-\} being put on, the meaning changes to "the person who plays".

(7) "Hal ini adalah kehormatan dan kami sekaligus meminta petunjuk agar Parfi bisa lebih kokoh dan maju.” Ujar Alicia

(Solopos)

In data (7) there is a sentence containing a polymorphemic word, namely petunjuk. The word is the result of the affixation process with the prefix as its constituent element. This process can be illustrated as follows:

$$
\{\operatorname{per}-\}+\operatorname{tunjuk}(\mathrm{v})=\operatorname{petunjuk}(\mathrm{n})
$$

This affixation affects the change in the word class and changes in the original meaning which is known as the derivation process. The word tunjuk comes from a word class of verb and then after getting the affix \{per-\} it changes to a noun. Meanwhile, in terms of meaning, originally the word tunjuk means "to point", but because of the prefix $\{$ per- $\}$ it changes to "something to show" or "to tell".

Next, the last prefix that causes a word class change to become a noun after being juxtaposed with other words is the prefix $\{$ se- $\}$. This can be seen in data (8), (9), and (I0).

(8) Lalu seputar matanya dihiasi lagi dengan eye shadow.

(Corat-Coret di Toilet)

In data (8) there is a sentence that contain a polymorphemic word seputar. The word is the result of the affixation process with the prefix as its constituent element. This process can be illustrated as follows:

$$
\{\mathrm{se}-\}+\operatorname{putar}(\mathrm{v})=\operatorname{seputar}(\mathrm{n})
$$

This affixation affects the change in the word class and changes in the original meaning which is known as the derivation process. The word putar comes from a verb word class and then after getting the affix $\{\mathrm{se}-\}$, it changes to a noun. Meanwhile, in terms of meaning, originally the word putar meant "dizzy", but because of the prefix $\{\mathrm{se}-\}$ it changed to "around (as in direction)" or "around (as in approximately)".

(9) Ia berpusat pada penyesuaian-penyesuaian harapan yang dibuat oleh para pembaca ketika mereka membaca sepanjang teks itu.

(Panduan Pembaca Teori Sastra Masa Kini)

In data (9) there is a sentence that contains a polymorphemic word sepanjang. The word is the result of the affixation process with the prefix as its constituent element. This process can be illustrated as follows:

$$
\{\text { se- }\}+\text { panjang }(\mathrm{a})=\operatorname{sepanjang}(\mathrm{n})
$$

This affixation affects the change in the word class and changes in the original meaning which is known as the derivation process. The word panjang comes from the adjective word class and then after getting the prefix $\{\mathrm{se}-\}$ it changes to a noun. Meanwhile, in terms of meaning, originally the word panjang meant 'far away', but because of the prefix $\{$ se- $\}$ it changed to "as far as" or "according to length".

(I0) Pemberian honorarium atau jasa profesi atas keterlibatan dalam karya bidang kebudayaan selama tanggap darurat dan pasca-pandemi Covid-19.

(Solopos)

In data (IO) there is a sentence that contains the word polymorphemic, namely selama. The word is the result of the affixation process with the prefix as its constituent element. This process can be illustrated as follows:

$$
\{\text { se- }\}+\operatorname{lama}(\mathrm{a})=\operatorname{selama}(\mathrm{n})
$$

This affixation affects the change in the word class and changes in the original meaning which is known as the derivation process. The word lama comes from the adjective word class and then after getting the prefix \{ se- 
\} it changes to a noun. Meanwhile, in terms of meaning, originally the word lama meant 'the length of between' or 'the length of time', but due to the prefixing $\{\mathrm{se}-\}$ it changed to 'all the time' or 'the time'.

Based on the findings above, the nouns that were formed could derive several types of nouns, such as abstract nouns, professions, actors, and tools. The word pejabat was included in the noun profession because it means someone who has a position or profession. There was also the word pemain which was included in the noun because it means the person who does an action. In addition, the word kehendak was included in an abstract noun because it has a meaning as a description of a state which is invisible to the eye. This shows that when viewed from a derivation perspective, affixing can derive various types of nouns (Ermanto dan Emidar, 20I I). The type of nomination was also different depending on the attached affixes and what lexem is attached to. Directly proportional to this, the resulting meaning is also different depending on the grammatical process (affixation) of the word (Sunaryo, 20I4).

On the other hand, the word pejabat and pemain formed deverbal nouns. It happens because of the derivation process that changes the meaning of a verb-class lexeme to a noun-class one. These deverbal nouns are formed from the distribution between derivative affixes, one of which can be a prefix (Nugraha, 2017). In this study, the prefixes that can form deverbal nouns are $\{\mathrm{pe}-\}$ and $\{$ per- $\}$ so that the pattern pe $+\mathrm{D}=\mathrm{NDv}$ and per $+\mathrm{D}=\mathrm{NDv}$ are formed. In addition to creating patterns of form, this process also creates patterns of meaning (Utama, 2019). Some of them mean professions and actors. Affixes that form deverbal nouns have different productivity, in this study the prefix $\{$ pe- $\}$ dominated with 62 prefixes. This shows that that prefix is productive, that is, a prefix capable of being attached to lexemes (Fijayanti, 2016). On the other hand, this also strengthens the opinion of (Kridalaksana, 2007) that the prefixes $\{$ ke- $\},\{$ pe- $\},\{$ per- $\}$, and $\{$ se- $\}$ could form nouns in Indonesian.

This shows that the process of derivation is closely related to other linguistic phenomena, especially at the morphological level. Therefore, it is necessary to have concrete evidence to know this process, for example in fiction or non-fiction writing, to news in newspapers. On the other hand, the process of derivation will be more understandable in its application (reading form), not just in theory (Zuhro, 2019). Returning to the concept of derivation, it is classified as a process of forming a word from another lingual unit which becomes a lexeme (Chaer, 20I5). This is in line with what was stated by Purnanto (2006), which is related to the event of forming a word which can create a new word in which the lexical identity differs from the lexeme. For example, the word pejabat which comes from the lexeme jabat then gets the prefix $\{\mathrm{pe}-\}$ which causes a change in the lexical identity from the previous meaning of 'doing' into 'profession'.

\section{Conclusion}

Based on the description of the results and the discussion in the previous section, it can be concluded that there are four derivative prefixes to form nouns in Indonesian i.e., the prefix $\{\mathrm{ke}-\},\{\mathrm{pe}-\},\{$ per- $\}$, and $\{\mathrm{se}-\}$. This research is in line with the theory of Kridalaksana (2007) in Pembentukan Kata dalam Bahasa Indonesia. The noun-forming prefix $\{\mathrm{ke}-\}$ can be derived from the affixing of the derivative affix $\{\mathrm{ke}-\}$ to a lexeme of adverb, adjective, and verb types so that the following three affixation patterns are formed $\{\mathrm{ke}-\}+\mathrm{Adv}=\mathrm{N},\{\mathrm{ke}-\}+\mathrm{A}$ $=\mathrm{N}$, dan $\{\mathrm{ke}-\}+\mathrm{V}=\mathrm{N}$. Next, the noun-forming prefix $\{\mathrm{pe}-\}$ can be derived from the affixing of the derivative affix $\{\mathrm{pe}-\}$ to the adjective and verb type of lexeme so that two affixation patterns $\{\mathrm{pe}-\}+\mathrm{A}=\mathrm{N}$ and $\{\mathrm{pe}-\}+$ $\mathrm{V}=\mathrm{N}$ are formed. Furthermore, the prefix $\{$ per- $\}$ that forms nouns can be derived from the affixing of derivative affixes $\{$ per- $\}$ in verb type lexemes to form a pattern of affixation $\{$ per- $\}+V=N$. Finally, the prefix $\{$ se- $\}$ which forms a noun can be derived from the affixing of the derivative affix $\{\mathrm{se}-\}$ in the lexeme of the adjective and verb types so that two affixation patterns $\{\mathrm{se}-\}+\mathrm{A}=\mathrm{N}$ and $\{\mathrm{se}-\}+\mathrm{V}=\mathrm{N}$ are formed. The change in lexical identity (meaning and word class) from verbs, adjectives, and adverbs to nouns in Indonesian indicates that the process of derivation is found in a variety of written languages, both informal and formal.

\section{Acknowledgement}

The authors would like to express special thanks of gratitude to Bp. Bakdal Ginanjar, S.S., M.Hum. who have given suggestions and input to the authors in the process of writing this article. In addition, the authors also thank all those who have conveyed their support and assistance in completing this article. 


\section{References}

Booij, Geert. (2007). The Grammar og Words: An Introduction to Linguistic Morphology. New York: Oxford University Press Inc.

Chaer, Abdul. (2015). Morfologi Bahasa Indonesia (Pendekatan Proses). Jakarta: Rineka Cipta.

Ermanto dan Emidar. (20II). Afiks Derivasi Per-/-An dalam Bahasa Indonesia: Tinjauan dari Perspektif Morfologi Derivasi dan Infleksi. Bahasa dan Seni, I2 (I). 23-34.

Fijayanti, Laurafita H. (2016). "Nomina Deverbal dalam Bahasa Indonesia". Skripsi.

Kridalaksana, Harimurti. (2007). Pembentukan Kata dalam Bahasa Indonesia. Jakarta: Gramedia Pustaka Utama. Kurniawan, Eka. (2014). Corat-Coret di Toilet. Jakarta: Gramedia Pustaka Utama.

Mahsun. (2012). Metode Penelitian Bahasa: Tahapan Strategi, Metode, dan Tekniknya. Jakarta: Rajawali Pers.

Nida, E. A. (1952) Morphoogy: The Descriptive Analysis of Word. Ann Arbor: The University of Michigan Press.

Nugraha, A. Danang Satria. (2017). Afiks-afiks Derivasional dan Tipe-tipe Nomina dalam Kontruksi Verba Denominatif Bahasa Indonesia. Bahasa dan Seni, 45(I). I3-26.

Purnanto, Dwi. (2006). Kajian Morfologi Derivasional dan Infleksional dalam Bahasa Indonesia. Kajian Linguistik dan Sastra, 18 (35). I36-I52.

Ramlan, M. (2009). Morfologi: Suatu Tinjauan Deskriptif. Yogyakarta: CV. Karyono.

Selden, Raman. (199I). Panduan Pembaca Teori Sastra Masa Kini. Yogyakarta: Gadjah Mada University Press.

Setiawan, Rio Dimas. (2017). Afiksasi Pembentukan Nomina dalam Kumpulan Cerpen "Lupa Endonesa” Karya Sujiwo Tejo. Skripsi.

Subroto, Edi. (20I0). Pengantar Metode Linguistik Struktural. Surakarta: Sebelas Maret University Press.

Sudaryanto. (2015). Metode dan Teknik Analisis Bahasa: Pengantar Penelitian Wahana Kebudayaan secara Linguistis. Yogyakarta: Diandra Primamitra.

Sunaryo. (20I4). Penggunaan Prefiks Bahasa Indonesia dalam Percakapan Informal Siswa. Edu-Kata. I(2). II9I30.

Utama, Moh. Rosya. (20I9). Afiks Pembentuk Nomina Deverbal dalam Bahasa Indonesia. Skripsi.

Verhaar, J. W. M. (2016). Asas-Asas Linguistik Umum. Yogyakarta: Gadjah Mada University Press.

Zuhro, Fatimatuz. (2019). Proses Derivasi dan Infleksi dalam Bahasa Indonesia pada Berita Koran Jawa Pos Radar Jombang Edisi Juli 2019. Disastri, 2 (I). I-8. 